\title{
ESTIMATION OF THE EFFICIENCY OF THE INVESTMENT FUND
}

\author{
Edward Dadyan \\ Associate Professor, Department of Data Analysis and Machine Learning, \\ Financial University under the Government of the Russian Federation \\ Moscow, Russian Federation \\ E-mail:dadyan60@yandex.ru \\ ai@mdpi.com. \\ ORCID ID \\ https://orcid.org/0000-0003-0332-6586 \\ JEL Classification: C45, C53, E37
}

\begin{abstract}
In this article, a search for a calculation method and an analysis of performance indicators of mutual investment funds is carried out. Many factors can influence the return on investments in portfolio investments, which makes the choice of the fund incredibly difficult. However, in addition to the fact that it is difficult to determine which indicators should be given more attention and which should be omitted, it is not so easy to get these data. Some of them are publicly available on the Internet, while others can only be found in trading systems that are not accessible to people outside of this area.

The article proves that a well-trained neural network can easily find existing patterns between risk and expected return on investment. It is a well-trained neural network that provides the ability to use the "what-if" function to justify your choice on real factors, as well as the ability to download available data and calculate the estimated income and its changes. This makes it much easier to choose a Fund, especially for inexperienced investors.

The article also presents the results of a study of the dependence of estimated income on correlation, standard deviation, and volatility using a trained neural network. According to the theory, higher values of these three factors correspond to a higher amount of income. The obtained graphs of the calculated income dependence on correlation, standard deviation, and volatility confirmed the correctness of the neural network training and compliance with the relations described in the theory. The paper presents graphs of the dependence of the estimated income on the beta and alpha coefficients. The higher the beta and alpha indicators, the higher the expected return on investment. This corresponds to the dependency accepted in the model. When the values of the beta and alpha coefficients increase, the income also increases, which is completely consistent with the theory.
\end{abstract}

Keywords: Efficiency of mutual funds, a deep crisis in the economy, efficiency forecast, model formation, financial investments, estimated income, mutual funds, CAPM, neural networks

\section{INTRODUCTION}

The financial crisis that began in 2007 resulted in significant losses and bankruptcies in several European banks. As the United States began to rebuild its economy from the crisis, Europe found itself embroiled in a new debt crisis. During economic changes, people began to look for alternatives to bank deposits that could ensure both the safety of money and its possible growth. In Europe, this type of service is offered by various investment funds such as mutual funds, hedge funds, pension funds, and insurance funds. According to research agencies, over the past 10 years, there has been a steady growth in popularity and, as a result, an increase in the number of mutual funds in Europe (Fig. 1). 


\section{billion $€ \quad$ the number}

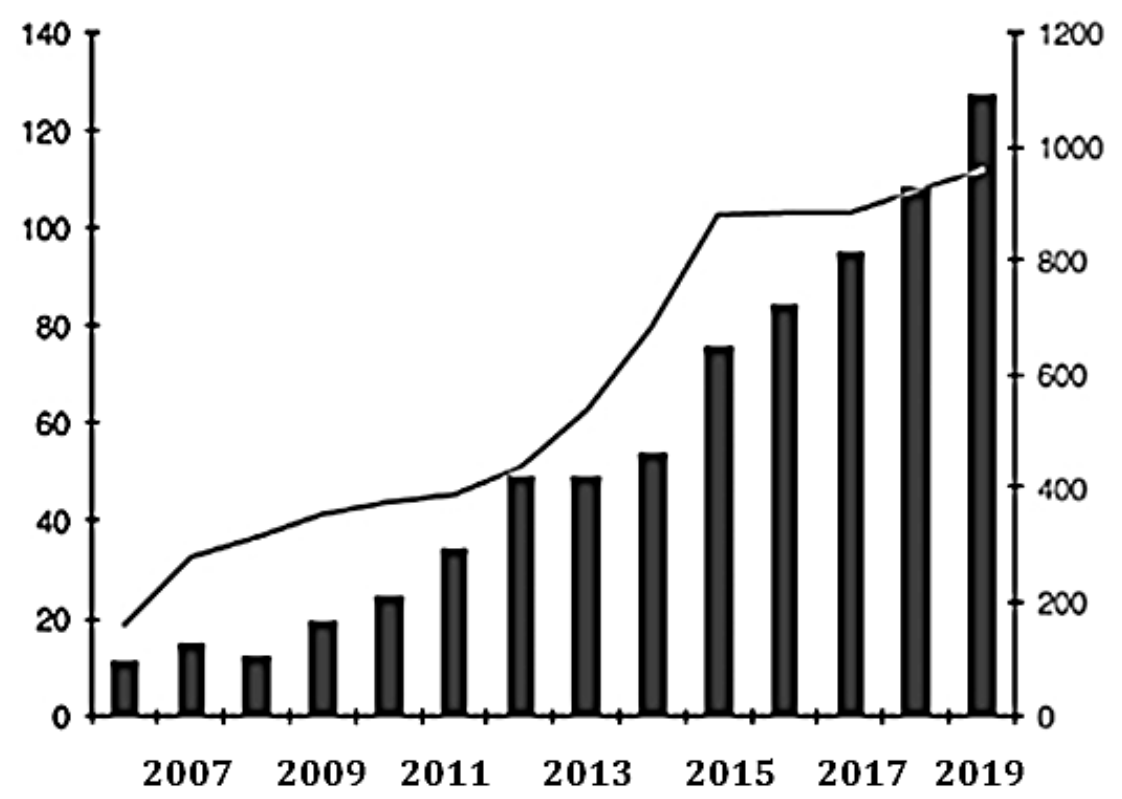

Fig. (1). European market opens mutual funds (until June 2019)

Source: oekom (2019). "Market data sustainability mutual funds."

In the Russian market of PIFs, there was also a noticeable increase in the number of funds, especially during the crisis (Figure 2).

This is due to investors' preference for these funds over less profitable Bank deposits and the entry of many of the largest Russian enterprises into financial markets,

Undoubtedly, the low "entry threshold" in mutual funds, which is kept at about 5,000 rubles, also played a crucial role in the popularity of mutual funds, allowing not only professional investors to invest in well-diversified portfolios of securities, but also people who do not have enough experience and funds.

\section{Number of funds}

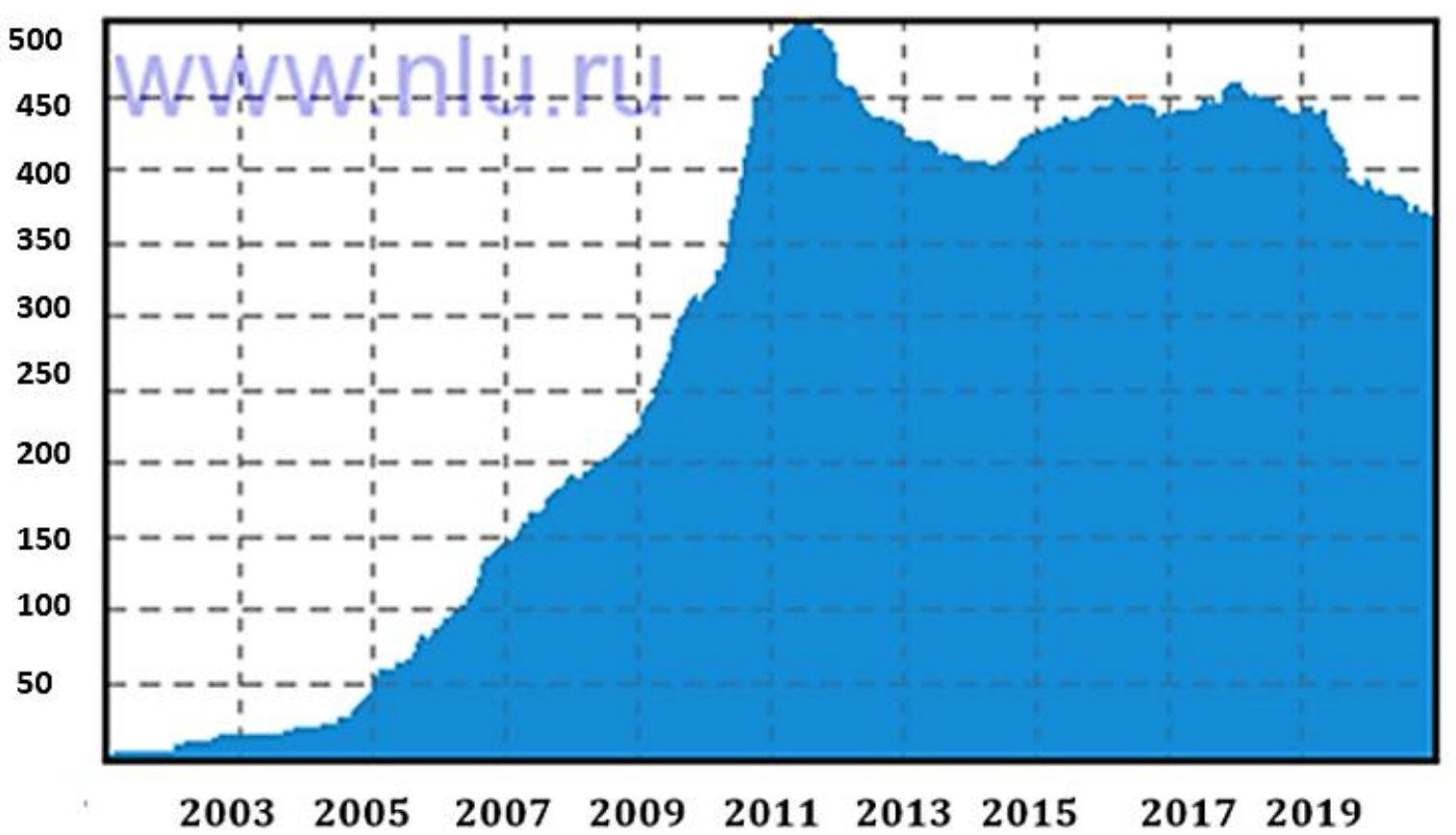

Fig. (2). Dynamics of the number of Russian funds operating. Source: National League of Managers (NLU). 
To choose a Fund to invest in, an investor must consider several factors: the field of activity in which they want to invest, the strategy and category of the Fund depending on expectations, ratings of investment funds, risk indicators, and indicators of return and investment performance that reflect how the Fund operates in the market.

According to professional investment portfolio managers, the most important factors in evaluating funds are the "beta" and "alpha" coefficients [1], while the model for evaluating financial assets (the CAPM model, hereinafter referred to as CAPM), which is directly related to them, can be considered quite informative.

The purpose of this work is to study the factors that significantly affect the risk assessment of financial investments and to predict their effectiveness using neural networks.

To achieve this goal, it was necessary to solve the following tasks:

- Identify factors that have a significant impact on the future profitability of financial investments in mutual funds.

- Identify the available risk indicators.

- Determine the model of the capital asset pricing CAPM.

- Analyzing risk indicators and predicting the expected return on investment in mutual funds using neural networks.

Due to several advantages, the analytical neural network platform Deductor Studio, developed in the Russian Federation by BASE GROUP, was chosen as the carrier of the neural network [2].

In the future, the structure of the work is determined taking into account the degree of development of the topic, based on the purpose and objectives of the study.

\section{NEURAL NETWORKS IN EVALUATING THE EFFECTIVENESS OF A MUTUAL FUND. BRIEF OVERVIEW LITERATURE}

During economic changes, individuals began to look for alternatives to bank deposits that could provide both the safety of money and its possible growth. In Europe, this type of service is offered by various investment funds such as mutual funds, hedge funds, pension funds, and insurance funds. According to research agencies, over the past 10 years, there has been a steady rise in popularity and therefore an increase in the number of mutual funds in Europe. Accordingly, there is a growing need to find ways to select profitable investment funds. Interesting results have been obtained by various authors in studies based on artificial neural networks.

It is shown in [3] that artificial neural networks have certain characteristics that make them useful in the development of controllers at different control levels, which micro nets must include to be economical, efficient, and able to meet the quality and quantity of energy requirements. The goal of this work is to draw attention to the promising applicability of artificial neural networks for controlling the distributed generation of microgrid sources, as well as for planning, power distribution, control, and optimization.

In [4], neural networks are considered that can process multidimensional data. It is shown that such neural networks overcome the problem of crosstalk, they are suitable for the implementation of associative memory and provide greater resistance to noise.

The paper [5] examines the impact of culture on mutual funds around the world. It explores how culture affects mutual funds around the world. It is shown how the values of the main performance indicators of the Fund affect the choice of an investment Fund in many countries.

The paper [6] considers the issues of pricing taking into account several stock market anomalies, examines the parameters of the indicators of mutual investment funds that affect pricing. Collectively, mutual funds are shown to have more weight than overvalued stocks and less weight than undervalued stocks compared to the passive benchmark. Also, it is proved that mutual funds with the largest share of undervalued shares outperform mutual funds with the largest share of overvalued shares. 
It is recognized in the literature [7] that there is a negative relationship between the return on the fund and the exit from it. This article analyzes the performance of 6,600 US mutual funds that left the market between 2000 and 2014 and nearly double the number of US mutual funds that continued to operate, to provide evidence of whether there was a negative exit versus performance relationship during the financial crisis. The 2008 year. The authors of the article show that the load on the fund's yield increased during the crisis.

It is shown in [8] that the growth in the number of passive institutional investors in the US stock market raises questions about the impact of corporate governance on their portfolio companies. Although the existing literature documents positive changes in governance, with passive institutional ownership crowding out retail ownership, it remains unclear how passive institutional ownership approaches corporate governance differently from their active counterparts. This article compares proxy voting behavior between passive and active mutual funds of the same family with identical investing styles.

Mutual investment funds of corporate bonds are engaged in the transformation of liquidity [9]. This is causing concern among academics and policymakers. They argue that large repayment payments will result in a sell-off of assets. However, the article's authors argue that there is little evidence that bond fund redemption is causing selling price pressure.

The current research in [10] is mainly focused on developing a quantitative forecasting model that can determine the future performance of Pakistani mutual funds at the investment policy level. For this purpose, the stochastic modeling method was considered, which is mainly based on the Monte Carlo simulation method, as a result of which the averages and variances of the observed means of the corresponding scenarios in the future are obtained with accuracy. The combination of the effects of the proposed scenarios led the authors to conclude that there is an impulse effect for all categories of mutual funds, except for "other funds". This research facilitates timely assessment of mutual fund classes.

The main purpose of the article [11] is to analyze the financial indicators of energy and renewable energy mutual funds using conditional and unconditional models.

The article [12] examines the welfare properties of mutual funds in the Diamond-Dybvig economy with two sources of aggregate risk: a shock for long-term investment returns and a shock for aggregate demand for liquidity. It is shown that mutual funds are ineffective when long-term investments are associated with risk. Using data from 2009 to 2016, the authors of [13] showed that Chinese mutual fund managers were pumping and dumping some of their core assets around the end of the quarter. The data suggest that fund managers are involved in manipulation to either create a stellar fund for a family of funds or directly increase their compensation.

The paper [14] explores the motivation and consequences of a deliberate change in the style of Fund management exclusively within a company in China. Because of the style drift, Fund investors are faced with an investment portfolio that goes beyond their risk and returns preferences but are generally unaware that their risk and return expectations are disrupted and the functioning of the stock market is compromised. Research by the authors shows for the first time the incentive that motivates the behavior of style drift, that style drift increases the subsequent net capital inflow of the Fund, that larger funds have more incentives to leave, that style drift hinders the selection of quality stocks to ensure the return of the Fund for investors.

In [15], a new approach to analyzing data coverage in neural network diversification is presented, which divides the overall efficiency of a mutual fund over the entire investment interval into efficiency in separate periods. In most models of diversification, the Analysis of the coverage of the data is nonlinear.

The empirical results presented in [16] show that the proposed models over the efficiency of diversification can distinguish well between effective funds, and a linear combination of effective funds can be ineffective. Moreover, the results of testing on a history show that the proposed models of super diversification efficiency usually have value for effective practice when choosing a portfolio. The goals of the authors of article [17] are to identify evidence of institutional investor behavior and to study their role in managing mutual funds. This behavior is explored in this paper by examining the variance over time of the beta version of UK open and 
closed funds. The study provides evidence of fund managers' behavior, suggesting that they tend to behave cooperatively based on a market portfolio, size, and value factors.

In [18], an equilibrium model is developed to explain why few mutual fund managers consistently outperform, although many have strong informational advantages. The key point is that managers receive investment ideas through the exchange of ideas. The exchange of ideas improves the statistical significance of the alpha by increasing the informative value of the price. But it also encourages more informed managers to take on larger positions, which makes their alphas noisier, even though a significant proportion of managers create strong informational advantages, statistical significance, and alpha consistency in underperforming funds.

In papers [19], [20], [21], methods are considered that are typical for complex studies of neural networks. Neural network technologies have been applied to analyze the characteristics of investment styles and similarities in Italian pension funds. The results of the study showed that the network structure of Italian pension funds contains sufficient information to identify similarities in investment styles.

The main goal of the authors of works [22], [23] the goal was to divide the EU countries into groups that are similar in terms of emissions of individual gases and dust into the atmosphere. The results of the grouping were considered as additional information, which was then used in the preparation of specific action plans to improve the state of the environment. The developed methodology and the conducted research allowed the authors to solve a significant research problem, and the results obtained can be successfully used in practice. Identification of groups of similar countries in the structure of emissions of harmful substances required the development of both an appropriate methodology and relevant research. This methodology is presented in the works under consideration, namely the Kohonen artificial neural network model. The main goal of the developed methodology was to divide the EU countries into groups that are similar in terms of emissions of individual gases and dust into the atmosphere using neural network technologies.

In the studies, the results of which are described in [24], [25], a neural network model is analyzed that predicts the Sharpe ratio. The developed neural network model makes it possible to predict the position of an investor who will be rewarded with an additional risk premium on debt securities at the same level of portfolio risk or a higher risk premium than the proportional growth risk. The main goal of the study is to predict the highest Sharpe ratio in the future. The study grouped data on the yield of debt instruments in the periods before, during, and after the global crisis. The results show that neural networks successfully predict nonlinear time series with $82 \%$ accuracy on test cases to predict the dynamics of the Sharpe ratio in the future and the position of the investor's portfolio.

The studies described in [26], [27] present the results of big data management. The papers show that one of the current challenges is accurate data validation and increasing the value of validated data for the organization and its stakeholders. Therefore, the goal of these papers is to develop an understanding of how authors can strategically tackle today's challenges in strategic big data management related to data validity and value.

\section{THEORETICAL ASPECTS OF THE DEVELOPED THEME}

Let us consider the factors that have a significant impact on the profitability and, therefore, the choice of the fund. These include types of funds, their categories, and their impact on future income, as well as risk indicators and models for evaluating financial assets.

Mutual funds are mutual funds that allow the investor to own a stake in a well-diversified portfolio of securities. The simplest mutual fund uses the main cost savings for individual investors, in both administrative and transaction costs, to maintain a liquid, diversified position.

There are two types of mutual funds: public and private investment companies. Public investment companies sell shares to clients and are required to redeem them on demand, with the ability to continuously issue new shares. Thus, shares of public companies are bought and sold directly from the fund at their net worth, which is set once a day, and are not traded on stock 
exchanges. Closed-end investment companies operate according to a different scheme, issuing a certain number of shares when the fund is established and selling them to clients. The company uses the proceeds to buy and sell securities traded on the stock exchange. Closed-end investment companies are not entitled to an additional issue of their shares. Elton et al. [28] compare investing in such funds with buying shares in any corporation, given that its assets are different securities.

When choosing a Fund, the strategy used in managing the investment portfolio is of key importance. There are two strategies for managing mutual funds: active and passive. Active management of a mutual Fund involves choosing stocks and bonds by the portfolio Manager and performing more frequent trading operations. This type of asset management involves involving large risks, and, consequently, obtaining largely expected revenues. This strategy makes sense in target market areas, such as emerging markets, where the Manager performs operations based on the results of a thorough technical and fundamental analysis of securities. Active Fund management often implies outperforming market indicators of profitability by getting rid of unprofitable assets, but a study conducted by Petahisto [29] shows that on average, mutual funds using the strategy of active portfolio management lose to reference portfolios.

The strategy of passive portfolio management is considered less risky, since it involves full or partial copying of the index, due to which mutual funds that use this type of management are also called index funds. In index funds, there is almost no trading, only in rare cases changes in the index structure, due to which the Fund's costs for a passive strategy are extremely small. Elton and co-authors [28] noted that although index funds are expected to lose on average compared to market dynamics, many low-cost funds exceed market performance because some stocks are sold at a higher price than expected when calculating the expected return on the index. No Fund with a passive management strategy matches the index in terms of returns calculated on a monthly or annual basis.

Before investing money in this or that fund, you should determine the expectations of an individual from investments. Various categories of funds offer the opportunity to increase their investments in the short or long term, or to ensure the safety of investments. An individual bears a different degree of risk depending on the category. Gitman et al. [30] distinguish the following categories of funds:

- growth funds,

- high-risk equity funds,

- value equity funds,

- income-oriented funds,

- funds focused on growth and income,

- balanced funds.

According to Gitman and co-authors [30], growth funds provide long-term growth and capital income by increasing the valuation of capital. The main range of companies considered by these funds includes small, medium, and large companies with the potential for further growth and a tendency to a high price/profit ratio, which makes it possible to expect that the profit will correspond to the high valuation of the company. Growing companies and growth funds can cover all levels of capitalization. Barras and co-authors [31] and Gitman and co-authors [30] argue that these types of funds do not provide for payment of dividends and current income. Despite the high level of risk exposure, Barras and co-authors note that the indicators of profitability of growth funds are close to the General indicators of the market for shared funds.

High-risk equity funds, according to Barras et al., Have better returns. Gitman and coauthors also refer to them as performance funds due to their tendency to grow during the market recovery. High-risk equity funds focus on relatively small companies with high price/earnings ratios and volatility. Due to their high level of risk and strong dependence on market conditions, high-risk equity funds are considered less stable than growth funds. While these two categories of funds show the best rates of return, they also carry high costs.

Value equity funds, unlike growth funds, focus on undervalued companies with expected 
growth, quite reliable, but unnoticed by investors. Barras et al. note that the high risk of such funds is offset by historically higher returns.

In contrast to the categories of funds described above, income-oriented funds do not set themselves the goal of increasing the valuation of the cost of capital, they focus on capital gains and, as a result, capital preservation. Gitman et al., Barras et al., And Brown and Reilly [32] describe income-oriented funds as funds that put money in companies that consistently generate high dividends, which makes such funds quite conservative. This category is considered a low risk due to the tendency to own high-quality securities with less volatility than the entire market.

Balanced funds are intermediate between income-oriented funds and growth funds. They invest in both stocks and bonds, providing both current income and long-term capital income. Gitman et al note that they are very similar to income-based funds in structure, but that they invest more in fixed-income securities.

Growth and income-oriented funds serve the same goals as balanced funds but invest more in stocks and focus on capital gains rather than recurring income. This category tends to focus more on high-quality earning stocks and growth-oriented blue chips. Because growth and income funds focus more on capital income, they are more exposed to risk.

Daniel et al. [33] found that growth funds and high-risk equity funds outperform incomeoriented or growth-and-income funds in terms of performance that is consistent with the goals and objectives of the funds.

The basis for choosing a fund is determining the goals of the investor. Depending on the focus on preserving capital or its growth and the desired level of risk, the investor chooses between the available strategies and categories of the fund. Upon further consideration, an individual can choose between funds subject to commission payments and not. Since the latter types of funds do not have a strong influence on the fund's performance indicators, their role in choosing an investment company is not as important as the role of strategies and categories of funds.

The choice between a public and private company depends on both the availability of circulation and the preferences of the investor. While the lower the investor's risk by guaranteeing to buy back their shares, shares of a closed company can provide additional income for the investor when they speculate on the stock exchange.

At the same time, the central factors in choosing a fund are the risks that the investor bears and the profitability that can guarantee the effectiveness of investments.

An analysis of the works of the above authors showed that the main attention should be paid to the following indicators of the risk of investment efficiency:

- standard deviation,

- volatility,

- correlation,

- "Beta" coefficient,

- "Alpha" coefficient,

- CAPM financial asset pricing model.

Standard deviation is a risk indicator associated with fluctuations in the price of an asset (stock, bond, property, etc.), or the risk of a securities portfolio or fund. This indicator provides a mathematical estimate of the uncertainty of future earnings. Like many other risk metrics, a higher standard deviation is considered to correspond to a higher return on investment. The sample standard deviation is used to calculate another indicator - volatility.

Volatility is a statistical financial indicator, also associated with price fluctuations, but in contrast to the standard deviation, it directly shows the frequency of price changes. It is the most important financial indicator and concept in financial risk management, where it is a measure of the risk of using a financial instrument for a given period. It is assumed that the higher the volatility value, the more risk the investor bears when investing.

Another indicator that can be attributed to risk is a correlation. In this case, we mean the correlation between the investment portfolio and the securities market. 
Correlation shows the relationship between income from a portfolio of securities and market returns. The correlation coefficient changes in the interval $[-1 ;+1]$. If the correlation is equal to 1 , the income from the investment portfolio will change in the same direction as the market income. Presumably, this is characteristic of index funds, that is, portfolios with a passive management strategy. Accordingly, with a correlation equal to -1, portfolio income moves in the opposite direction relative to market income.

According to publications, much attention is paid to the beta and alpha indicators.

The beta coefficient "is a measure of systematic risk, that is, the risk arising from the impact of macroeconomic and political factors on the company's activities and the stock market" [34]. This indicator has similarities to correlation. It also shows the relationship between earnings per share and average market earnings. "From the theory, it follows that $\beta=1$ means that the profitability of a particular stock and the market changes in the same way. If $\beta>1$, the profitability of the stock grows faster than the market profitability, which indicates the riskiness of this stock. Security with $\beta<1$ is characterized as secure and remains less risky than the market. From this, we can conclude that the lower the beta, the less risky the investment. And accordingly, the greater $\beta$, the higher the investor's risk "[30]. The beta coefficient is used as the main risk indicator when calculating the estimated income using the CAPM model.

Alpha coefficient - shows how much of the income to the shareholders was brought by the skill of the manager, and not by the growth of the market.

The higher the alpha value, the greater the profitability the manager was able to get on a conventional unit of relative risk assumed. The ratio shows whether the fund has managed to exceed the rate of return that can be expected based on its Beta level. A high value of the alpha coefficient indicates the skill of a manager, a negative value indicates a low efficiency of management, taking into account the ratio of the portfolio to market risks.

The Capital Asset Pricing Model (CAPM) is used to determine the required level of return on an asset, which is supposed to be added to an existing well-diversified portfolio, taking into account the market risk of this asset. CAPM predicts the expected return on investment depending on three indicators: the risk-free interest rate, the expected return on the market, and the beta of the investment.

The financial asset pricing model aims to explain the behavior of stock prices. Portfolio Risk and return are considered together with the impact of stocks on them through a financial asset pricing model. CAPM predicts the expected return on investments depending on three indicators: the risk-free interest rate, the expected return on the market, and the beta coefficient on investments (1).

$$
r_{j}=R_{F}+\left[\beta_{j} *\left(R_{m t}-R_{F}\right)\right]
$$

Where $r_{j}=$ expected return on investment $\mathrm{j}$, with risks expressed as a beta coefficient,

$R_{F}=$ risk-free interest rate of return; income that can be received on risk-free securities,

$\beta_{j}=$ beta coefficient or index of non-diversified risk on investments $\mathrm{j}$,

$R_{m t}=$ expected market return; average return for all stocks (usually measured as the the average return for all stocks in the Standard \& poor's 500 - Stock Composite Index or some other major stock market index).

The discovery of the financial asset pricing model led to the development of a series of indicators that calculate investment efficiency: Sharpe ratio, Trainor ratio, and Jensen's alpha coefficient.

Jensen's alpha measures excess income expressed as the amount of deviation of real return on investment from expected. If Jensen's alpha is negative, then

investments did not bring the expected income, with a positive coefficient, investments bring more than the expected income, and with alpha equal to zero, the income received is exactly 
equal to the expected one. The indicator is calculated as the difference between the risk premium and the market premium multiplied by the beta coefficient (2).

$$
\alpha_{p}=r_{p}-\left[R_{F}+\left[\beta_{p} *\left(R_{m t}-R_{F}\right)\right]\right]
$$

Where $\alpha_{\mathrm{p}}=$ above the standard return on price error above and below the level of income expected for the CAPM,

$r_{p}=$ expected return on investments,

$\mathrm{R}_{\mathrm{F}}=$ the interest rate of return-free from risk; income that can be received on securities free from risk,

$\beta_{\mathrm{p}}=$ beta coefficient or index of non-diversified risk on investments,

$\mathrm{R}_{\mathrm{mt}}=$ expected market return.

By the formula, a linear relationship is traced_between the expected return on investment and the alpha indicator. The higher the revenue, the higher the alpha indicator will be.

\section{LEARNING THE NEURAL NETWORK}

It is necessary to consider how the neural network interprets the above dependencies, to analyze the results of training the neural network on the training set obtained using the Bloomberg trading system used by professional investors (Table 1). Table 2 contains test data required to test the performance of the neural network.

Table 1. The fragment of data received from the trading system Bloomberg

\begin{tabular}{|c|c|c|c|c|c|c|c|c|c|c|c|c|c|c|c|}
\hline $\begin{array}{l}\text { № } \\
\text { 0/n }\end{array}$ & Name & Category & Country & $\mathrm{Rm}, \%$ & Rf, $\%$ & $\begin{array}{c}\text { Return } \\
\text { (Last } \\
\text { close) (\%) } \\
\text { YTD }\end{array}$ & $\begin{array}{c}\text { Return } \\
\text { (Last } \\
\text { close) (\%) } \\
1 \text { Year }\end{array}$ & $\begin{array}{c}\text { Return } \\
\text { (Last } \\
\text { close) (\%) } \\
3 \text { Year }\end{array}$ & \begin{tabular}{|c|} 
Return \\
(Last \\
close) (\%) \\
5 Year \\
\end{tabular} & Beta & Alpha & $\begin{array}{c}\text { Sigma } \\
\text { SD }\end{array}$ & $\begin{array}{l}\text { Corre } \\
\text { lation }\end{array}$ & Sigma & CAPM \\
\hline 1 & A54FUND:AV & Growth & Austria & 14,58 & 3,8 & 1,673 & 3,662 & 1,82 & 2,151 & 0,051 & 0,055 & 0,214 & 0,312 & 2,011 & 4,354 \\
\hline 2 & AHCOACC SM & Growth & Spain & 12,59 & 5,3 & 7,849 & 2,049 & $-3,692$ & 0,243 & 1,379 & $-0,075$ & 1,699 & 0,882 & 29,909 & 15,35 \\
\hline 3 & AIAKTIV:NO & Growth & Norway & 14,48 & 3,83 & $-0,65$ & 18,85 & 4,154 & 2,85 & 0,946 & 0,015 & 0,64 & 0,979 & 20,99 & 13,909 \\
\hline 4 & AKTCAPA:FH & Growth & Finland & 10,93 & 3,57 & 0,167 & 13,652 & 1,893 & 3,208 & 0,876 & 0,002 & 1,313 & 0,892 & 18,285 & 10,016 \\
\hline 5 & AKTWELT:GR & Growth & Germany & 13,02 & 3,35 & $-1,215$ & 4,702 & 0,657 & $-0,159$ & 0,411 & 0,044 & 1,113 & 0,702 & 10,854 & 7,325 \\
\hline 6 & ALLDWAP:GR & Growth & Germany & 13,02 & 3,35 & $-1,433$ & 6,761 & 2,17 & $-1,537$ & 0,826 & 0,006 & 1,056 & 0,868 & 15,851 & 11,336 \\
\hline 7 & ALTBOLA:SM & Growth & Spain & 12,59 & 5,3 & $-0,476$ & $-0,069$ & $-3,117$ & $-3,003$ & 0,967 & $-0,148$ & 0,45 & 0,982 & 17,116 & 12,353 \\
\hline 8 & ALZHEOJ:GA & $\begin{array}{l}\text { Growth } \\
\text { and } \\
\text { income }\end{array}$ & Greece & 14,29 & 12,84 & 5,581 & $-20,201$ & $-20,513$ & $-12,294$ & 0,847 & $-0,009$ & 0,8 & 0,979 & 25,774 & 14,069 \\
\hline 9 & APOLL34;AV & $\begin{array}{l}\text { Growth } \\
\text { and } \\
\text { income }\end{array}$ & Austria & 14,58 & 3,8 & $-1,159$ & $-1,153$ & 5,159 & 4,236 & 0,428 & $-0,002$ & 0,605 & 0,376 & 3,008 & 8,416 \\
\hline 10 & BANBOEU:SM & Growth & Spain & 12,59 & 5,3 & 5,158 & 4,334 & $-1,893$ & $-2,501$ & 0,987 & 0,015 & 0,509 & 0,984 & 21,019 & 12,493 \\
\hline 11 & BANEURO:SM & Growth & Spain & 12,59 & 5,3 & 1,737 & 1,759 & $-5,642$ & $-4,289$ & 0,859 & $-0,03$ & 0,398 & 0,987 & 18,189 & 11,559 \\
\hline 1441 & USINTEC:LX & Growth & $\begin{array}{l}\text { Luxemb } \\
\text { ourg }\end{array}$ & 12,2 & 3,35 & 2,102 & 11,441 & 7,706 & 4,929 & 0,9 & $-0,008$ & 0,364 & 0,989 & 18,489 & 11,314 \\
\hline 1442 & WWOSAEB:GR & $\begin{array}{l}\text { Growth } \\
\text { and } \\
\text { income }\end{array}$ & Germany & 13,02 & 3,35 & $-0,284$ & 1,549 & $-3,251$ & $-3,6$ & 1,009 & $-0,016$ & 0,433 & 0,985 & 17,666 & 13,102 \\
\hline 1443 & A54FUND:AV & Growth & Austria & 14,58 & 3,8 & 1,673 & 3,662 & 1,82 & 2,151 & 0,051 & 0,055 & 0,214 & 0,312 & 2,011 & 4,354 \\
\hline 1444 & AHCOACC:SM & Growth & Spain & 12,59 & 5,3 & 7,849 & 2,049 & $-3,692$ & 0,243 & 1,379 & $-0,075$ & 1,699 & 0,882 & 29,909 & 15,35 \\
\hline
\end{tabular}


Table 2. Test data to verify the quality of networks.

\begin{tabular}{|c|c|c|c|c|c|c|c|c|c|c|c|c|c|c|c|}
\hline $\begin{array}{l}\text { № } \\
\text { п/n }\end{array}$ & Name & Category & Country & Rm, \% & Rf, \% & \begin{tabular}{|c|} 
Return \\
(Last \\
close) (\%) \\
YTD \\
\end{tabular} & \begin{tabular}{|c|} 
Return \\
(Last \\
close) (\%) \\
1 Year
\end{tabular} & \begin{tabular}{|c|} 
Return \\
(Last \\
close) (\%) \\
3 Year
\end{tabular} & \begin{tabular}{|c|} 
Return \\
(Last \\
close) (\%) \\
5 Year
\end{tabular} & Beta & Alpha & $\begin{array}{l}\text { Sigma } \\
\text { SD }\end{array}$ & $\begin{array}{l}\text { Corre } \\
\text { lation }\end{array}$ & Sigma & CAPM \\
\hline 1 & BANBOEU:SM & Growth & Spain & 12,59 & 5,3 & 5,158 & 4,334 & $-1,893$ & $-2,501$ & 0,987 & 0,015 & 0,509 & 0,984 & 21,019 & 12,493 \\
\hline 2 & BANEURO:SM & Growth & Spain & 12,59 & 5,3 & 1,737 & 1,759 & $-5,642$ & $-4,289$ & 0,859 & $-0,03$ & 0,398 & 0,987 & 18,189 & 11,559 \\
\hline 3 & BRGUKIILN & $\begin{array}{l}\text { Growth and } \\
\text { income }\end{array}$ & England & 12,11 & 3,69 & $-0,852$ & 8 & 4,611 & 2,699 & 0,423 & 0,07 & 0,7 & 0,837 & 8,282 & 7,251 \\
\hline 4 & CAIGEUB:SM & $\begin{array}{l}\text { Growth and } \\
\text { income }\end{array}$ & Spain & 12,59 & 5,3 & 4,71 & 0,164 & $-5,802$ & $-4,879$ & 1,259 & $-0,067$ & 0,552 & 0,986 & 26,335 & 14,48 \\
\hline 5 & CSSPSMS:SW & Income & Switzerland & 10,65 & 1,96 & $-0,726$ & 11,45 & 2,298 & 4,452 & 1,12 & 0,004 & 0,492 & 0,975 & 15,92 & 11,696 \\
\hline 6 & DANISTP:DC & $\begin{array}{l}\text { Growth and } \\
\text { income }\end{array}$ & Denmark & 14,08 & 3,59 & $-3,668$ & 4,455 & $-0,478$ & $-1,118$ & 0,9 & $-0,042$ & 1,508 & 0,724 & 17,128 & 13,028 \\
\hline
\end{tabular}

One of the most interesting applications of neural networks in recent years has precisely become the problem of financial activities. A huge number of universal neuro packages, which are often used to solve technical analysis problems, and specialized expert systems and neuro packages for solving many other, more complex and difficult to formalize problems from the financial field, appear on the market. At present, computers and software for neuro packages and neurocomputers designed to solve financial problems have appeared on the Russian market.

The use of neural network technologies as tools is promising in solving many poorly formalized problems, in the analysis of financial activities, exchange, stock, and foreign exchange markets associated with high risks of customer behavior patterns, etc. The forecast accuracy, consistently achieved by neural network technologies in solving real problems, has already exceeded $95 \%$. In the world market, neural network technologies are widely represented - from expensive systems on supercomputers to PCs, making them available for applications of almost any level.

The main advantages of neural networks include:

- the ability to learn from many examples in cases where the patterns of development of the situation and the function of dependence between the input and output data are unknown. In such cases (up to $80 \%$ of the problems of financial analysis can be attributed to them), traditional mathematical methods are not applicable.

- the ability to successfully solve problems based on incomplete, distorted, and internally contradictory input information.

- the ability to operate a trained neural network with any users.

- the ability to connect neural network packages extremely easily to databases, e-mail and automate the process of entering and primary data processing.

- internal parallelism is inherent in neural networks, which makes it possible to increase the power of the neural system almost infinitely, an ultra-high performance due to the use of massive parallelism of information processing.

- tolerance to errors - performance is maintained when a significant number of neurons are damaged.

- ability to learn - programming of a computing system is replaced by learning.

- the ability to recognize patterns in conditions of strong interference and distortion.

As a research tool, due to several advantages, the analytical neural network platform Deductor Studio, developed by BASE GROUP (Russian Federation, Ryazan), was chosen. A few words about this software product (www.basegroup.ru). Deductor Studio provides deep data analytics systems development covering data collection, consolidation, data cleaning, modeling, and visualization. Deductor Studio is designed to solve a wide range of tasks related to the processing of structured data presented in the form of tables. These tables of structured data form the so-called training choice, designed for training a neural network, forming an expert system of the studied subject area. At the same time, the area of application of the system can be practically any - the mechanisms implemented in the system are successfully used in financial markets, in insurance, trade, telecommunications, industry, medicine, in logistics and marketing 
tasks, and many others.

With the help of Deductor Studio, you can not only build models but also carry out analysis according to the "what-if" principle, i.e. to assess how this or that indicator can change when any influencing factor changes. To implement this easy-to-use yet powerful mechanism, a special renderer is designed. In this case, it does not matter in what way the model was built the work with all algorithms is performed in the same way. The results can be viewed both in tabular form and graphically.

Let us consider how the expected return on investment, calculated by the author using the CAPM financial asset valuation model, depends on certain indicators. These indicators are indicated in the header of table 1 . There are 14 of them: Name of the mutual fund, Category of the mutual fund, Country of the mutual fund, $\mathrm{Rm}(\%)$, Rf (\%), Income per day (\%), Income for the year $(\%)$, Income for 3 years (\%), Income for 5 years $(\%)$, betta, alpha, Sigma SD, Correlation, sigma. The listed parameters form a multidimensional (14 dimensional) set. We can conditionally say that the set under consideration has 14 dimensions. Any 14 elements, selected one from each dimension of the multidimensional set, define (generate) one element of the onedimensional CAPM set (Fig. 3). A set of CAPMs, in our opinion, can be viewed as a set of facts.

\begin{tabular}{|c|c|c|c|c|}
\hline \multicolumn{5}{|c|}{$\begin{array}{llllllllllll}M & E & A & S & U & R & E & M & E & N & T & S\end{array}$} \\
\hline $\begin{array}{c}\text { The Name of } \\
\text { the MUTUAL } \\
\text { FUND }\end{array}$ & $\begin{array}{c}\text { Category of } \\
\text { the MUTUAL } \\
\text { FUND }\end{array}$ & $\begin{array}{c}\text { Country of } \\
\text { the MUTUAL } \\
\text { FUND }\end{array}$ & $\mathrm{Rm},(\%)$ & Rf, (\%) \\
\hline Sigma & \multirow[t]{2}{*}{ FACTS } & \multirow{2}{*}{ CAPM } & & $\begin{array}{l}\text { Return (Last } \\
\text { close) (\%) } \\
\text { YTD }\end{array}$ \\
\hline Correlation & & & & $\begin{array}{c}\text { Return (Last } \\
\text { close) (\%) } \\
1 \text { Year }\end{array}$ \\
\hline Sigma SD & Alpha & Beta & $\begin{array}{l}\text { Return (Last } \\
\text { close) (\%) } \\
5 \text { Year }\end{array}$ & $\begin{array}{l}\text { Return (Last } \\
\text { close) (\%) } \\
3 \text { Year }\end{array}$ \\
\hline
\end{tabular}

Fig. (3). All fourteen elements, one from each dimension define a one-element one-dimensional array CAPM

After entering and processing data, Deductor Studio forms virtual storage containing elements of dimensions and facts. A so-called "training sample" is formed, which includes input data (measurements) and output data (facts). After establishing the appropriate parameters of the network, the training itself and the formation of a multiparameter expert system are performed. A block diagram of this process, as well as the execution of subsequent functional operations, is shown in Fig. 4.

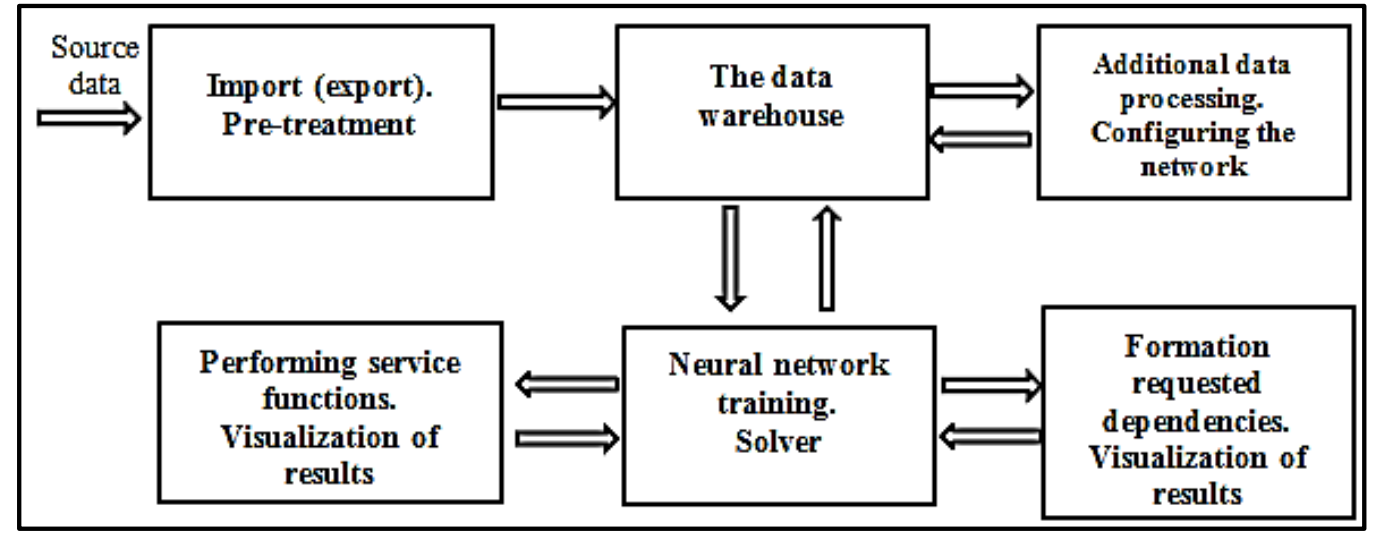

Fig. (4). The block diagram of the formation of a multi-parametric expert system 
When forming the network structure, we proceeded from the following prerequisites. There is no exact rule on how many layers and neurons a network must-have for good learning [1]. Many authors write that there should not be too many neurons, otherwise it will lead to poor functioning of the network - it will remember values, instead of finding patterns. However, too few neurons will negatively affect the network. The same authors recommend choosing from a range of 5 to 17 neurons.

To train the neural network, two of fourteen parameters were transferred to the "informational" category ("name" and "country", as not essential), eleven - to the "input" category, as significant in terms of their influence on the formation of the CAPM output parameter (Fig. 5 ). It should be noted that the names of the funds and the country were defined as informational only to distinguish one fund from another, one country from another. They were not introduced as an "input" parameter, as the names themselves cannot have any effect on the fund's income.

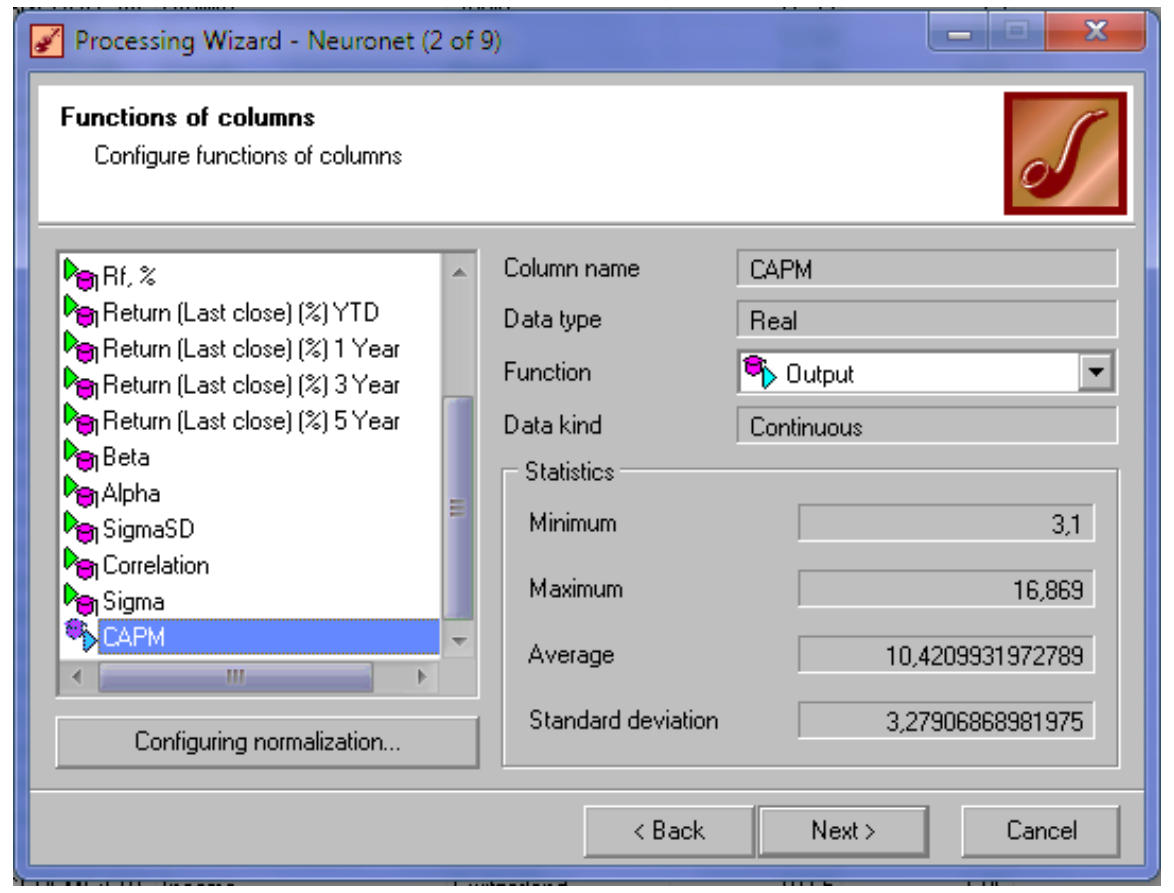

Fig. (5). Configure destination parameters

In the process of investigating various settings of the neural network structure, scatter diagrams of variants were compared with each other. As a result, the choice fell on the option shown in Figure 6 due to the relatively smaller deviation of the model's output values from the ideal line.

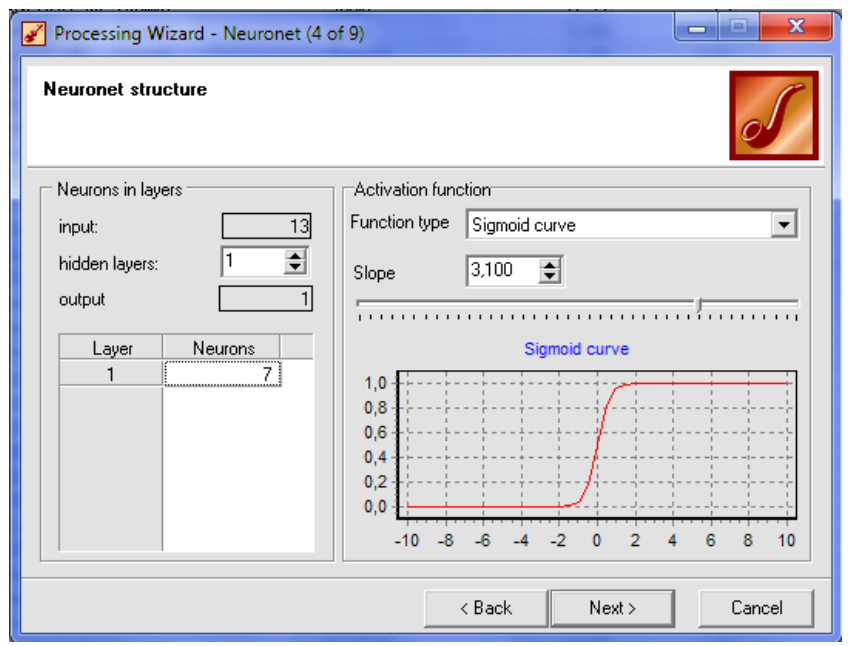

Figure 7 shows the scatter diagram of the trained neural network 
for the selected tuning option.

In our case, it can be seen (Fig. 7) that the deviations of the model output values practically coincide with the lines of the calculated CAPM values. We can conclude the successful training of the neural network and proceed to study the dependence of the CAPM financial asset valuation model on the various parameters described above.

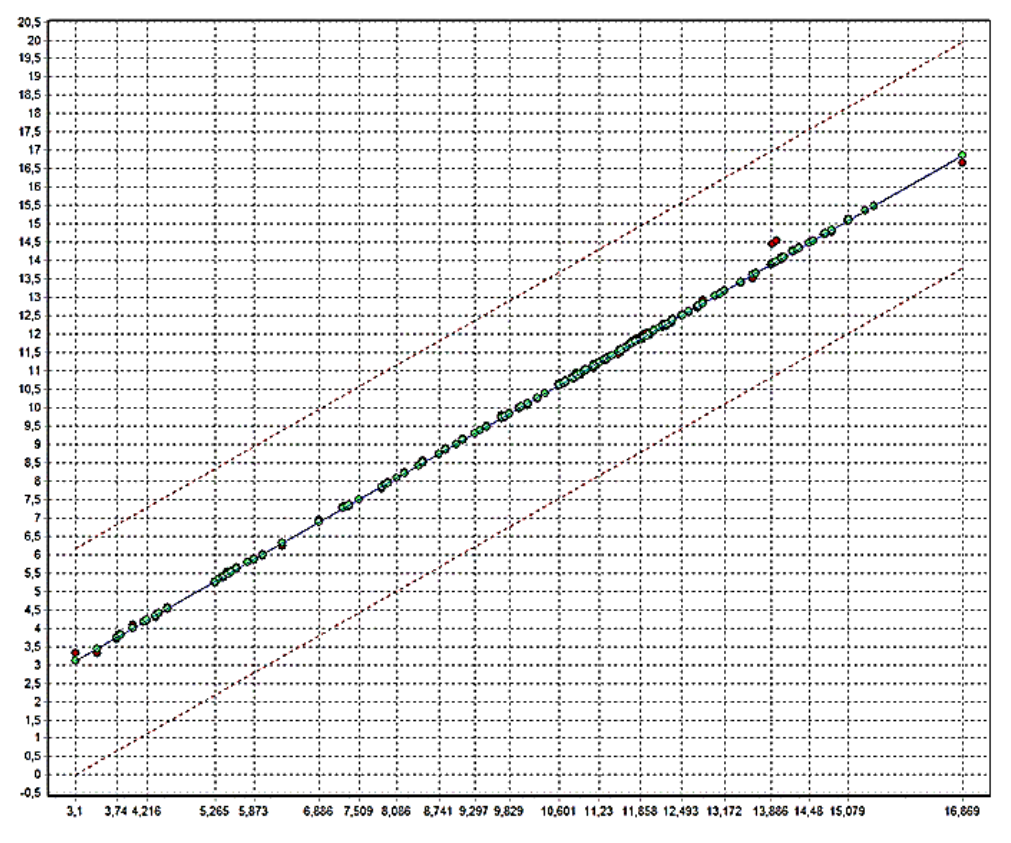

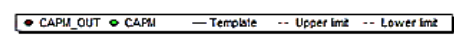

Fig. (7). Diagram of dispersion of trained neural network selection settings

Of interest is the neural network graph (Fig. 8). With its help, by color relationships and weight coefficients, one can judge the significance of a factor and the degree of its influence on the CAPM output parameter.

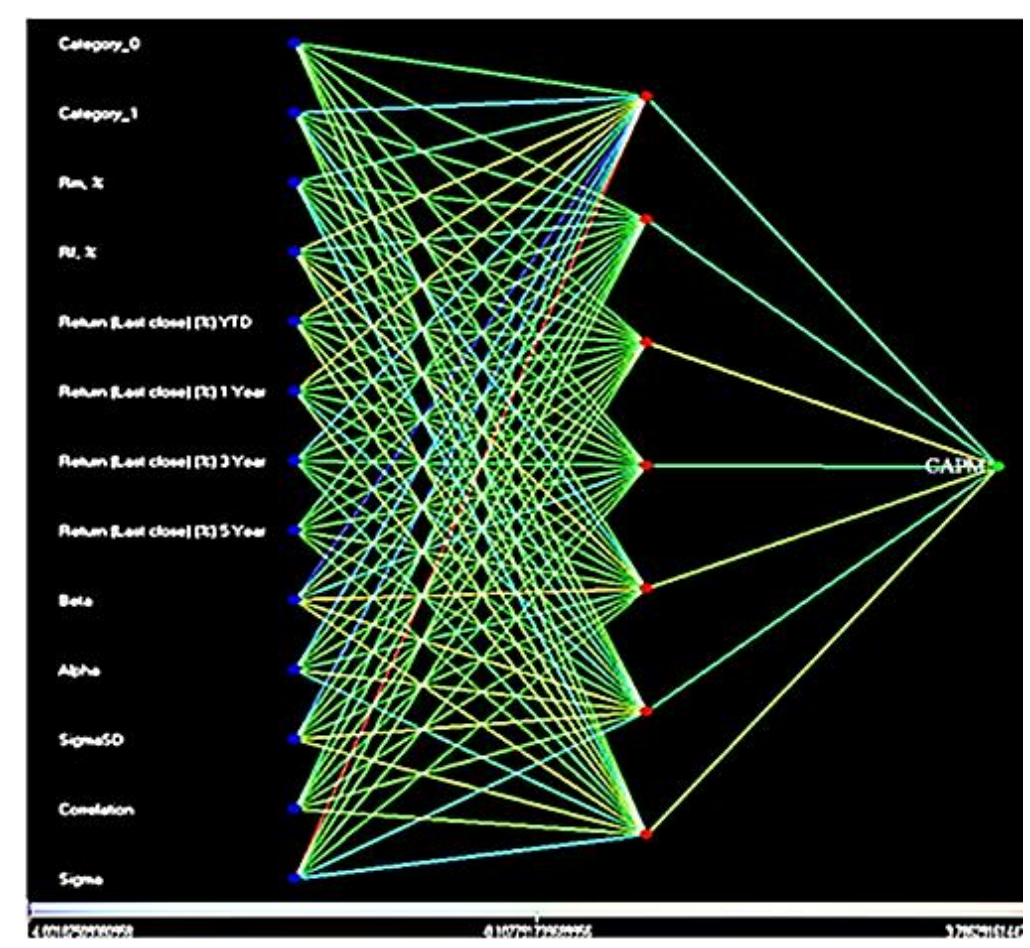

Fig. (8). Graf trained neural network selection settings

The diagram in question and all subsequent figures must be viewed and analyzed in color. 
The color of the process carries certain information. A black and white image loses this information with all the ensuing consequences. The conclusions that can be made by analyzing the neural network graph in our case, what is the weight of the influence of the selected essential parameters on the formation of the value of the CAPM parameter, are contained in the color of the communication lines of the identified input neuron with the corresponding neurons of the middle layer. The colored bar at the bottom of the figure is followed by numerical values.

It is practically impossible to obtain exact values of the averaged weight coefficients of the considered parameters; much depends on the analyst's color perception of communication lines, i.e. there is a subjective factor here. And, nevertheless, by color relationships and weight coefficients, one can judge the degree of influence of one or another input parameter on the output CAPM parameter.

After loading the data from Table 2 into the application, they were processed by the already trained network using the "Script" function in the Processing Wizard of the Deductor program. The replay of the CAPM_OUT data load differs little from the original CAPM value. The CAPM_ERR replay error can be considered insignificant (Table 3).

Table 3. Reproduction of data loading CAPM_OUT

\begin{tabular}{|c|c|c|c|c|c|c|c|c|c|c|c|c|c|c|c|c|}
\hline \multicolumn{2}{|c|}{ 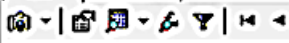 } & \multicolumn{2}{|c|}{$1 / 6$} & \multicolumn{13}{|c|}{ |-m|目 } \\
\hline Nano & Colegory & Counky & Am, $\%$ & Rf, $\%$ & $\begin{array}{c}\text { Return (Last } \\
\text { close) (t)YTD }\end{array}$ & Retum (Last close) (\%) & $\begin{array}{l}\text { Retum } \\
\text { [Losit close] } \\
\text { [i. 3Yyes }\end{array}$ & $\mid \begin{array}{c}\text { Retum } \\
\text { Rast dose) } \\
\text { (*) } 5 \text { Yeat }\end{array}$ & Bets & Apho & Sigmaso & Correlation & Signe & CAPM & CAPM_OUT & CAPM_ERR \\
\hline DEANBOEUSMI & Grownh & $5 \sin$ & 1259 & 5.3 & 5.158 & 4.334 & $\begin{array}{r}.1 .893 \\
\end{array}$ & 2.501 & 0.987 & 0.015 & 0.509 & 0.394 & 21.019 & 12.493 & 12.4930254403 & 0 \\
\hline QANEURO:SM & Growth & Spoin & 12.59 & 5.3 & 1,737 & 1,759 & .5 .642 & 4.209 & 0.859 & 0.03 & 0.398 & 0.997 & 18.169 & 11.559 & 11,5590269518 & 0 \\
\hline 8RGUXI:UW & Growenth andinocme & Endind & 12.11 & 369 & -0.852 & 8 & 4.611 & 2.699 & 0.423 & 0.07 & 0.7 & 0.837 & 8.282 & 7251 & 72511725499 & BE.10 \\
\hline CAIGEUB:SM & Grownh ond income & Spoin & 12,59 & 5.3 & 4.71 & 0,184 & .5 .802 & 4.879 & 1.259 & 0,067 & 0.552 & 0.986 & 26.355 & 14.48 & 14,4726350673 & 1.0368 \\
\hline CSSPSMS:SW & Income & Swizeriond & 10.65 & 1.26 & -0.726 & 11,45 & 2.298 & 4.452 & 1.12 & 0.004 & 0.492 & 0.975 & 15.92 & 11.696 & 11.6960135238 & 0 \\
\hline DOANISTP:OC & Growth and income & Dermak & 14.08 & 3.59 & .3 .668 & 4.455 & -0.478 & $-1,118$ & 0.9 & 0.042 & 1,508 & 0.724 & 17,128 & 13.028 & 13.0280172039 & 0 \\
\hline
\end{tabular}

\section{SELECTING A FUND USING A TRAINED NEURAL NETWORK}

Having a small set of data about the fund, which is insufficient to calculate the indicator of the estimated return on investment, but having a trained neural network available, you can find out the rate of return according to the financial asset valuation model and base your choice of the fund on it.

Numerous experiments carried out to confirm the above statement have revealed the following:

1. It should be remembered that the input data are divided into discrete and continuous by type.

2. For discrete elements: when forming a table for input into the trained neural network and calculating CAPM_OUT, the values of the elements are taken from those existing in the training set.

3. For continuous elements: when forming a table for input into the trained neural network and calculating CAPM_OUT, the values of the elements can be any located within the measurement boundaries of the corresponding element.

The element value of the $\mathrm{i}-$ th dimension must satisfy the condition:

$$
\operatorname{Min}_{\mathrm{i}}-3 *\left(\operatorname{Max}_{\mathrm{i}}-\operatorname{Min}_{\mathrm{i}}\right) / \mathrm{n}<=\mathrm{K}_{\mathrm{i}}<=\operatorname{Max}_{\mathrm{i}}+3 *\left(\operatorname{Max}_{\mathrm{i}}-\operatorname{Min}_{\mathrm{i}}\right) / \mathrm{n},
$$

Where: $\quad K_{i}-$ the value of the $\mathrm{i}-$ th dimension,

$\operatorname{Min}_{\mathrm{i}}-$ minimum value of the $\mathrm{i}-$ th measurement,

$\mathrm{Max}_{\mathrm{i}}$-maximum value of the $\mathrm{i}$ - th measurement,

$\mathrm{n}$ - number of elements in the dimension.

To get the values of the $\operatorname{Min}_{\mathrm{i}}, \mathrm{Max}_{\mathrm{i}}$ and $\mathrm{n}$ should order the option "Statistics" at the stage of determining how to display the results of the work of the master processing neural network. 
Then, the display mode of the results when the indicator of "statistics", the system will display the required table (table 4).

Table 4. The ordered table

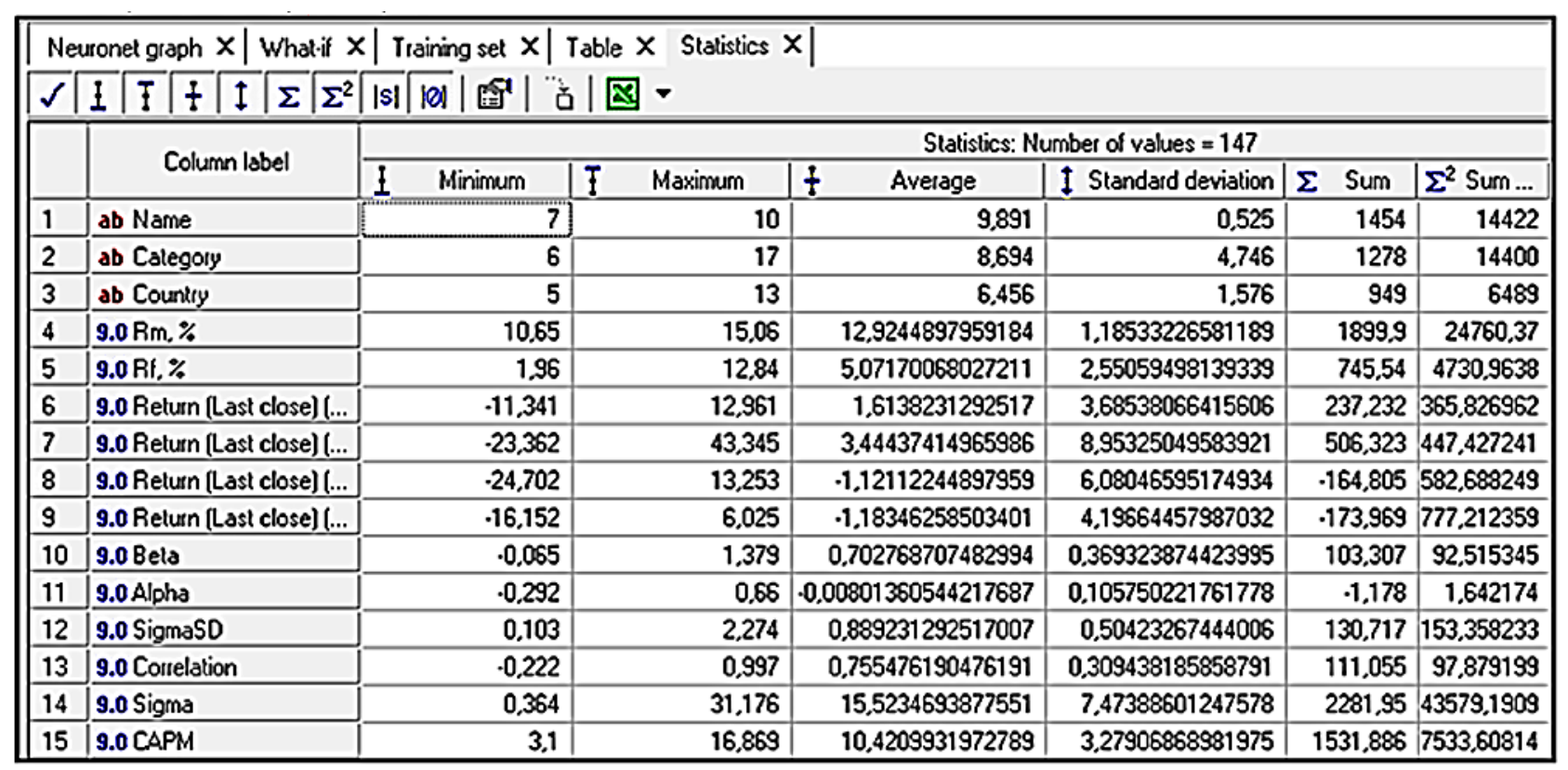

In the display mode of the trained neural network, ordering the "What if" mode, we get the following prompt to enter the generated measurement values (Fig. 9). The CAPM_OUT result is read almost immediately (Fig. 9).

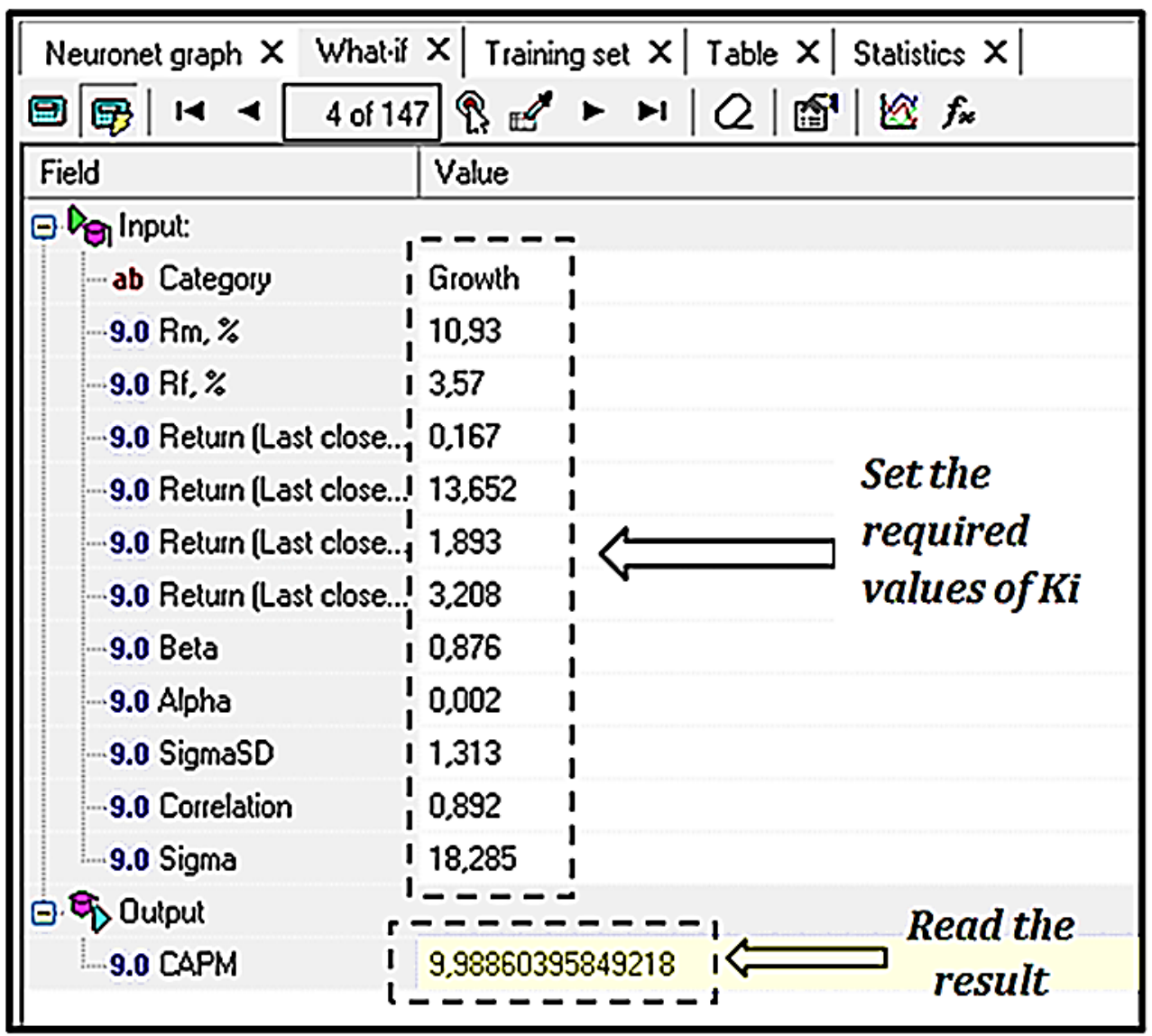

Fig. (9). Enter the generated measured values and reading the result 


\section{EXPERIMENTAL CONFIRMATION OF THEORETICAL RESULTS}

Further, to confirm the theory, we build graphs of the dependences of the estimated income on correlation, standard deviation, and volatility. According to theory, higher-income values correspond to higher values of these three factors.

Figure 10 shows the graphs of the dependence of the estimated income on the correlation, standard deviation, and volatility, identified by the neural network. They correspond to the relationships described in theory. The obtained dependencies once again confirm that the neural network has trained correctly.
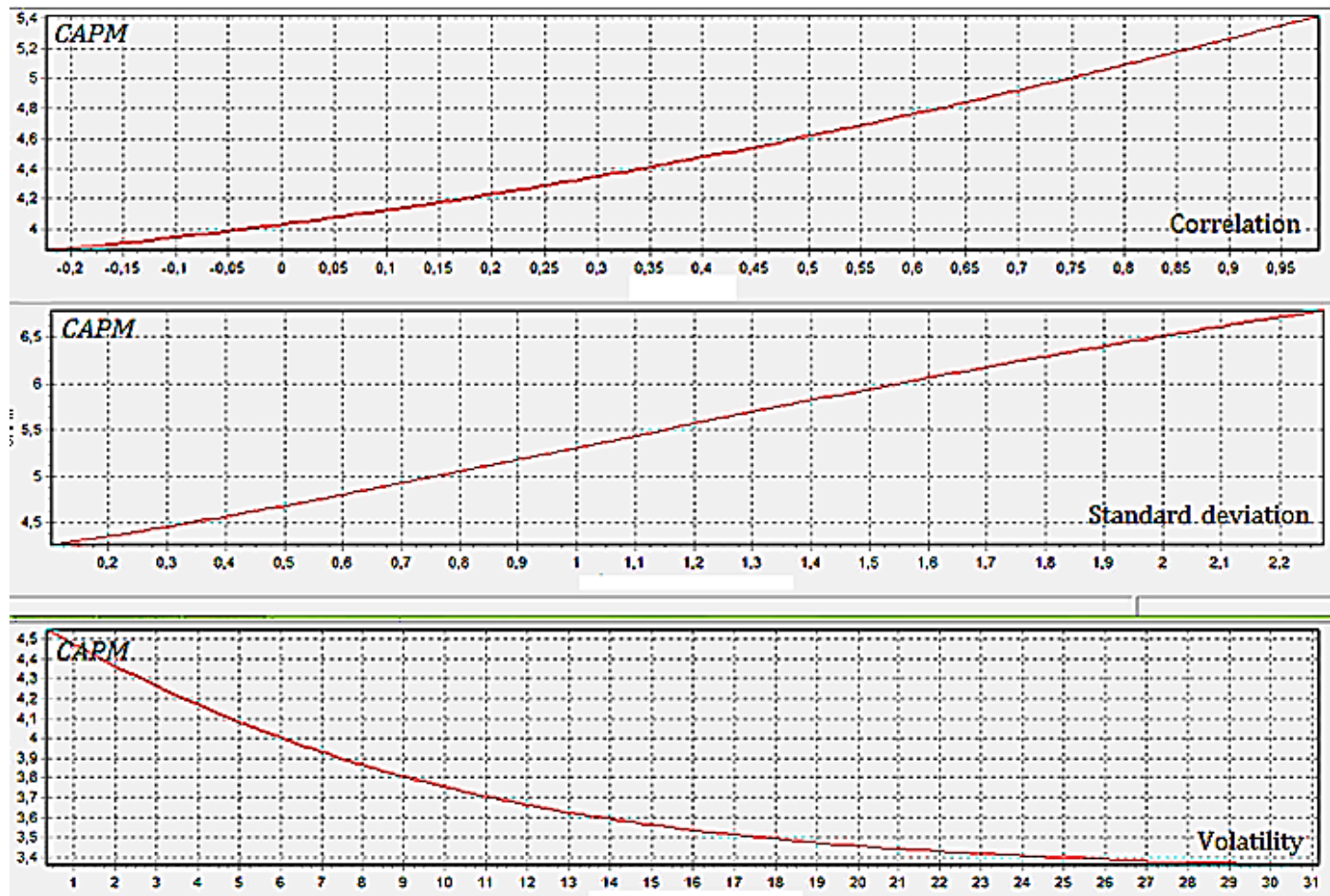

Fig. (10). The graphs of the expected revenue from the correlation, standard deviation and volatility

Figure 11 shows graphs of the estimated income versus beta and alpha. The higher the beta and alpha, the higher the expected return on investment. This corresponds to the dependency assumed in the model. With an increase in the values of the coefficient's beta and alpha, the income also increases, which is fully consistent with the theory.
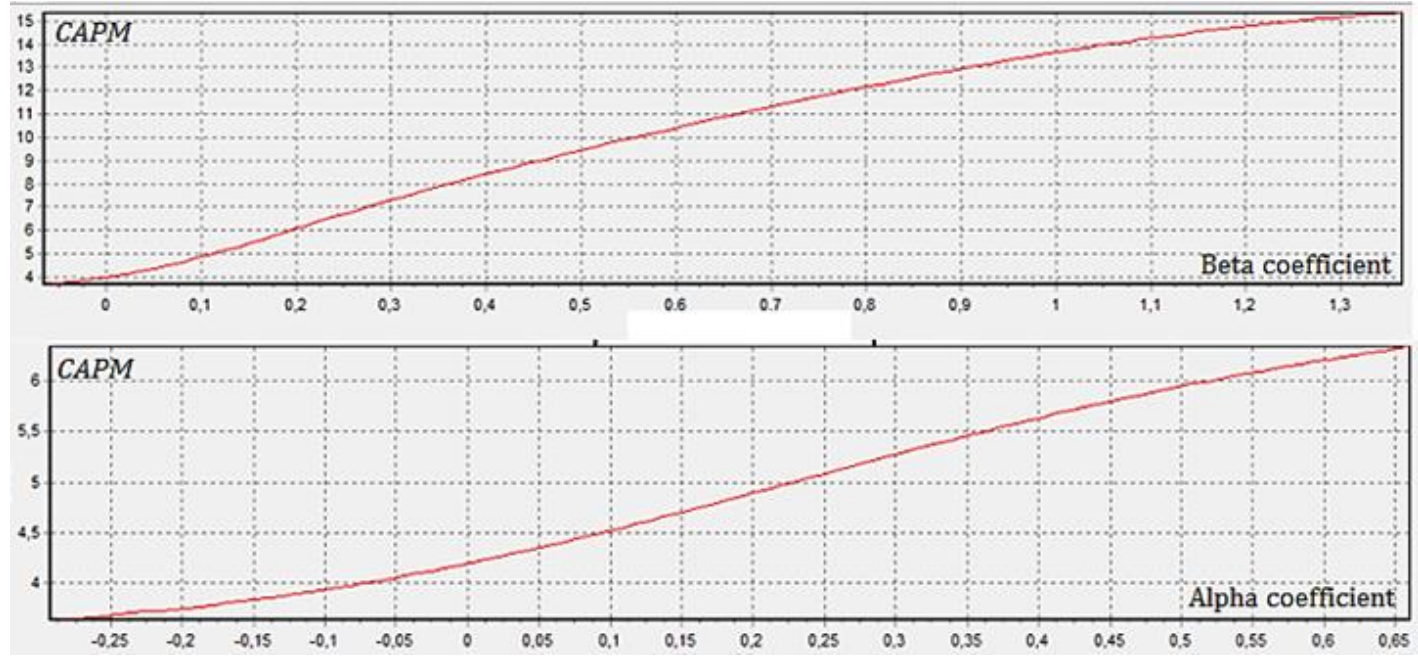

Fig. (11). The graphs of the expected revenue from the coefficients of beta and alpha 


\section{RESEARCH RESULT. POINTS FOR DISCUSSION}

Many factors can affect the return on investment in portfolio investments, which makes choosing a fund incredibly difficult. However, in addition to being difficult to determine which indicators should be given more attention and which should be omitted, it is not so easy to obtain this data. Some of them are in the public domain on the Internet, others can only be found in trading systems that are not accessible to people not associated with this field.

A trained neural network, which easily finds the existing patterns between risk and the expected return on investment, provides an opportunity using the "What-if" function to base its choice on real factors. It provides the ability to download existing data and calculate the estimated income and its changes. This greatly simplifies the choice of a fund for inexperienced investors.

For practical use, we recommend a neural network trained on public data. With its help, it is possible to calculate the future income for any fund, which will greatly simplify the choice of a fund for inexperienced investors and increase the motivation to invest in mutual funds. For advanced users, we propose a neural network training technique using our dataset to ultimately obtain the value of the CAPM financial asset pricing model.

\section{REFERENCES}

[1] Tania B.Lopez-Garcia, Alberto Coronado-Mendoza, José A.Domínguez-Navarro Artificial neural networks in microgrids: A review, Engineering Applications of Artificial Intelligence, Volume 95, October 2020, 103894, Received 3 June 2019, Revised 22 July 2020, Accepted 10 August 2020, Available online 20 August 2020. https://doi.org/10.1016/i.engappai.2020.103894

[2] Marcos Eduardo Valle, Rodolfo Anibal Lobo, Quaternion-valued recurrent projection neural networks on unit quaternions, Theoretical Computer Science, Theoretical Computer Science, Volume 843, 2 December 2020, Pages 136-152, Received 14 January 2020, Revised 8 July 2020, Accepted 30 August 2020, Available online 4 September 2020, https://doi.org/10.1016/j.tcs.2020.08.033

[3] Aneel Keswani, Mamdouh Medhat, Antonio F.Miguel, Sofia B.Ramos Uncertainty avoidance and mutual funds, Journal of Corporate Finance, Available online 5 October 2020, 101748, Received 17 October 2019, Revised 25 September 2020, Accepted 30 September 2020, Available online 5 October 2020. https://doi.org/10.1016/i.jcorpfin.2020.101748

[4] Jaeram Lee, Hyunglae Jeon, Jangkoo Kang, Changjun Lee, Do actively managed mutual funds exploit stock market mispricing? The North American Journal of Economics and Finance, Volume 53, July 2020, 101189, Received 9 April 2019, Revised 25 February 2020, Accepted 17 March 2020, Available online 19 March 2020.

https://doi.org/10.1016/j.najef.2020.101189

[5] Anna (Ania) Zalewska, Yue Zhang, Mutual funds' exits, financial crisis and Darwin, Journal of Corporate Finance, Volume 65, December 2020, 101738, Received 29 October 2019, Revised 29 June 2020, Accepted 8 September 2020, Available online 15 September 2020. 


\section{https://doi.org/10.1016/j.jcorpfin.2020.101738}

[6] Shenje Hshieh, Jiasun Lib, Yingcong Tangc, How do passive funds act as active owners? Evidence from mutual fund voting records, Journal of Corporate Finance, Available online 12 July 2020, 101692, Received 16 February 2019, revised 13 May 2020, Accepted 3 July 2020, Available online 12 July 2020.

https://doi.org/10.1016/j.jcorpfin.2020.101692

[7] Jaewon Choi, Saeid Hoseinzade, Sean Seunghun Shin, Hassan Tehranian, Corporate bond mutual funds and asset fire sales, Journal of Financial Economics, Available online 20 May 2020, Received 1 August 2018, Revised 9 September 2019, Accepted 7 October 2019, Available online 20 May 2020.

https://doi.org/10.1016/j.jfineco.2020.05.006

[8] Wajid Shakeel Ahmed, Jibran Sheikh, Kashif Ur-Rehman, Khurram Shafi, Shafqat Ali Shad, Faisal Shafique Butt, New continuum of a stochastic static forecasting model for mutual funds at the investment policy level, Chaos, Solitons \& Fractals, Received 3 January 2019, Revised 24 November 2019, Accepted 6 December 2019, Available online 20 December 2019.

https://doi.org/10.1016/j.chaos.2019.109562

[9] Carmen-Pilar Martí-Ballester, Do European renewable energy mutual funds foster the transition to a low-carbon economy? Renewable Energy, Renewable Energy, Volume 143, December 2019, Pages 1299-1309, Received 21 November 2018, Revised 19 March 2019, Accepted 22 May 2019, Available online 23 May 2019.

https://doi.org/10.1016/j.renene.2019.05.095

[10] Simas Kučinskas, Aggregate risk, and efficiency of mutual funds, Journal of Banking $\&$

Finance, Volume 101, April 2019, Pages 1-11, Received 21 January 2018, Revised 30 September 2018, Accepted 2 January 2019, Available online 31 January 2019. https://doi.org/10.1016/j.jbankfin.2019.01.001

[11] Liangyi Ouyang, Bolong Cao, Selective pump-and-dump: The manipulation of their top holdings by Chinese mutual funds around quarter-ends, Emerging Markets Review, Volume 44, September 2020, 100697, Received 10 July 2018, Revised 12 November 2019, Available online 8 April 2020.

https://doi.org/10.1016/j.ememar.2020.100697

[12] Angeline Kim, Pei Chua, On Kit Tam, The shrouded business of style drift in active mutual funds, Journal of Corporate Finance, Volume 64, October 2020, 101667, Received 9 December 2019, Revised 13 April 2020, Accepted 4 June 2020, Available online 10 June 2020. https://doi.org/10.1016/j.jcorpfin.2020.101667

[13] R. Lin, Z. Chen, Q. Hu, Z. Li, Dynamic network DEA approach with diversification to multi-period performance evaluation of funds, OR Spectr, 39 (2017), pp. 1-40

CrossRef View Record in Scopus Google Scholar.

[14] Ruiyue Lin, Zongxin Li, Directional distance-based diversification super-efficiency DEA models for mutual funds, Omega, Volume 97, December 2020, 102096, Received 2 February 2019, Revised 28 June 2019, Accepted 2 August 2019, Available online 3 August 2019.

https://doi.org/10.1016/j.omega.2019.08.003

[15] Yawen Hudson, Meilan Yan, Dalu Zhang, Herd behavior \& investor sentiment:

Evidence from UK mutual funds, International Review of Financial Analysis, Volume 71, October 2020, 101494, Received 1 August 2019, Revised 21 January 2020, Accepted 
27 March 2020, Available online 15 May 2020.

https://doi.org/10.1016/j.irfa.2020.101494

[16] Julien Cujean, Idea sharing and the performance of mutual, Journal of Financial. Economics, Volume 135, Issue 1, January 2020, Pages 88-119, Received 15 November 2016, Revised 13 August 2018, Accepted 4 September 2018, Available online 20 May 2019.

https://doi.org/10.1016/j.jfineco.2019.05.015

[17] Camilleri and Farrugia, 2018

S.J. Camilleri, R. Farrugia

The risk-adjusted performance of alternative investment funds and UCITS: A comparative analysis

International Journal of Economics and Finance, 10 (7) (2018), pp. 23-37

View Record in Scopus Google Scholar

[18] Ding et al., 2017

N. Ding, J. Parwada, J. Shen

Information sharing within the networks of delegated portfolio managers: Evidence from plan sponsors and their sub-advisers

Journal of Behavioral Finance, 18 (1) (2017), pp. 99-113

CrossRef View Record in Scopus Google Scholar

[19] Li et al., 2016

J. Li, D. Ren, X. Feng, Y. Zhang

Network of listed companies based on common shareholders and the prediction of market volatility

Physica A: Statistical Mechanics and its Applications, 462 (2016), pp. 508-521

Article Download PDF View Record in Scopus Google Scholar

[20] Rossi et al., 2018

A.G. Rossi, D. Blake, A. Timmermann, I. Tonks, R. Wermers

Network centrality and delegated investment performance

Journal of Financial Economics, 128 (2018), pp. 183-206

Article Download PDF View Record in Scopus Google Scholar

[21] Rotundo and D'Arcangelis, 2016

Rotundo, G. \& D'Arcangelis, A. M. (2016). Complex networks in finance. In P. Commendatore, M. Matilla-García, L.M. Varela, J.S. Cánovas (eds.), Complex networks and nonlinear dynamics. Lecture notes in economics and mathematical systems (Vol. 683, pp. 209-235). Springer. Google Scholar

[22] Varela Cabo, L. M. \& Rotundo, G. (2016). Complex network analysis and nonlinear dynamics. In P. Commendatore, M. Matilla-García, L.M. Varela, J.S. Cánovas (eds.), Complex networks and nonlinear dynamics. Lecture notes in economics and mathematical systems (Vol. 683, pp. 3-25). Springer. Google Scholar

[23] Obeidat S., Shapiro D., Lemay M., MacPherson M.K., Bolic M.

Adaptive portfolio asset allocation optimization with deep learning

Int. J. Adv. Intell. Syst., 11 (1 \& 2) (2018), pp. 25-34

View Record in Scopus Google Scholar

[24] Vukovic D.B., Ugolnikov V., Maiti M.

Analyst says a lot, but should you listen: Evidence from Russia

J. Econ. Stud., 47 (4) (2020). Google Scholar

[25] Vukovic D., Lapshina K., Maiti M. 
European monetary union bond market dynamics: Pre \& post-crisis

Res. Int. Bus. Finance, 50 (2019), pp. 369-380, 10.1016/j.ribaf.2019.04.001

Article Download PDF View Record in Scopus Google Scholar

[26] Shams S.M.R., Solima L.

Big data management: implications of dynamic capabilities and data incubator

Manage. Decis. (2019), 10.1108/MD-07-2018-0846

in press. Google Scholar

[27] Sohag K., Shams S.M.R., Omar N., Chandrarin G.

Comparative study on finance-growth nexus in Malaysia and Indonesia: Role of institutional quality

Strategic Change, 28 (5) (2019), pp. 387-398

CrossRef View Record in Scopus Google Scholar

[28] Elton, E. J., M. J. Gruber, Incentive Fees, and Mutual Funds. // The Journal of Finance - 2003 - 58(2) - c. 779-804

[29] Petajisto, A. (2010). "Active Share and Mutual Fund Performance." SSRN eLibrary

[30] Gitman, L. J., M. D. Joehnk, et al. (2010). Fundamentals of Investing, Prentice Hall

[31] Barras, L., O. Scaillet, et al. False Discoveries in Mutual Fund Performance: Measuring Luck in Estimated Alphas. // The Journal of Finance - 2010 - 65(1) - c. 179-216

[32] Brown, K. C. and F. K. Reilly (2009). Analysis of investments and management of portfolios, South-Western Cengage Learning.

[33] Daniel, K., M. Grinblatt, et al. (1997). "Measuring Mutual Fund Performance with Characteristic-Based Benchmarks." // The Journal of Finance - 1997 - 52(3) - c. 10351058

[33] Андреева Н.В., Демшин В.В. Оценка бизнеса: так ли уж хорош коэффициент БЕТА для расчета ставки дисконта // Вопросы оценки. - 2001. - №3 - Режим доступа: http://www.niec.ru/Articles/013.htm 